\title{
Erosion and abrasion on dental structures undergoing at-home bleaching
}

This article was published in the following Dove Press journal:

Clinical, Cosmetic and Investigational Dentistry

I 5 July 201 I

Number of times this article has been viewed

\author{
Flávio Fernando Demarco' \\ Sônia Saeger Meireles² \\ Hugo Ramalho Sarmento' \\ Raquel Venâncio Fernandes \\ Dantas' \\ Tatiana Botero ${ }^{3}$ \\ Sandra Beatriz Chaves Tarquinio' \\ 'Graduate Program in Dentistry, \\ School of Dentistry, Federal \\ University of Pelotas, Brazil; \\ ${ }^{2}$ Department of Operative Dentistry, \\ Federal University of Paraíba, Brazil; \\ ${ }^{3}$ Cariology, Restorative Science, \\ and Endodontics Department, School \\ of Dentistry, University of Michigan, \\ MI, USA
}

Correspondence: Flávio Fernando Demarco Universidade Federal de, Faculdade de Odontologia, Rua Gonçalves Chaves, 457 Centro CEP, 96015568 Pelotas, Brazil

Tel +5332226690

Fax +5332226690

Email flavio.demarco@pq.cnpq.br

\begin{abstract}
This review investigates erosion and abrasion in dental structures undergoing at-home bleaching. Dental erosion is a multifactorial condition that may be idiopathic or caused by a known acid source. Some bleaching agents have a $\mathrm{pH}$ lower than the critical level, which can cause changes in the enamel mineral content. Investigations have shown that at-home tooth bleaching with low concentrations of hydrogen or carbamide peroxide have no significant damaging effects on enamel and dentin surface properties. Most studies where erosion was observed were in vitro. Even though the treatment may cause side effects like sensitivity and gingival irritation, these usually disappear at the end of treatment. Considering the literature reviewed, we conclude that tooth bleaching agents based on hydrogen or carbamide peroxide have no clinically significant influence on enamel/dentin mineral loss caused by erosion or abrasion. Furthermore, the treatment is tolerable and safe, and any adverse effects can be easily reversed and controlled.
\end{abstract}

Keywords: peroxide, tooth bleaching, enamel, dentin, erosion, abrasion

\section{Introduction}

Dental appearance is gaining more importance in modern society. Today, a large number of patients are searching for personal satisfaction and increasing the demand for an attractive smile. Tooth bleaching has become one of the most popular cosmetic procedures offered in dental practice. ${ }^{1}$ Several products and techniques are available for vital tooth bleaching, and vary in concentration and type of end products released., . $^{2}$ The whitening procedures can be performed in the office by the dentist or at home by the patient without dentist supervision.

Overall, when applied over an enamel surface, the peroxide-containing agents break down into water and oxygen, which diffuse through the enamel, causing oxidation and reduction of organic pigments that are mainly located within dentin, resulting in a reduction or elimination of the discoloration. ${ }^{4}$

At-home vital tooth bleaching with custom trays is the most common modality used. ${ }^{5,6}$ The advantages of this treatment are its application, reduced chair time, safety and low incidence of tooth sensitivity. ${ }^{5-7}$ Supervised at-home tooth bleaching involves the use of custom trays loaded with low concentrations of carbamide $(10 \%-22 \%)$ or hydrogen peroxide gels $(3.4 \%-7.5 \%)$ that are used by the patient for a few hours per day. ${ }^{2,5}$ The side effects frequently associated with tray bleaching systems are gingival irritation and tooth sensitivity, which can either be related to shape of the tray or to concentration of the bleaching agent. ${ }^{8,9}$ 
In recent years, an increasing number of over-the-counter bleaching products have appeared in the market, which can be used by the patient at home without dentist supervision. These products have increased in popularity and represent a large percentage of the over-the-counter products sold for oral hygiene. Even though such products have low concentrations of peroxide agents, they may produce side effects, including an erosive effect on dental structure, because patients tend to ignore the manufacturers' recommendations and use them for a long period of time. ${ }^{10}$ Although the manufacturers have introduced different concentrations of bleaching agents onto the market, $10 \%$ carbamide peroxide gel is the only one that has a seal of acceptance from the American Dental Association assuring its safety and efficacy for at-home tooth bleaching. ${ }^{11}$

In an attempt to provide an evidence base for dental practitioners, the aim of this review was to evaluate the erosive potential of at-home bleaching agents, which could increase susceptibility to tooth abrasion. A literature search of the electronic database, MedLine, was performed up to February 28, 2011. The following search format was performed using Mesh terms: (“Tooth Bleaching”[Mesh]) AND ("Tooth Erosion"[Mesh] OR "Tooth Abrasion"[Mesh]).

\section{Erosion and abrasion related to tooth bleaching}

Tooth wear can be defined as a progressive loss of hard dental tissues due to the processes of abrasion and erosion. ${ }^{12}$ Dental erosion is an irreversible loss of tooth substance due to a chemical process without the presence of bacteria, ${ }^{13}$ while abrasion is caused by oral habits and the use of abrasive substances, such as abrasive toothpastes. ${ }^{14}$ Even though these processes can occur individually or together, the effect of erosion is often dominant. ${ }^{14-16}$ It has been suggested that for enamel demineralization to take place, the $\mathrm{pH}$ on the enamel surface must fall below 5.5. ${ }^{17}$

Dental erosion is a multifactorial condition that may be idiopathic or caused by a known acid source. ${ }^{18,19}$ Several acids, including some of those regularly found in the human diet, such as acidic food and soft drinks; or those originating in the stomach, like gastric acid from regurgitation or reflux, and some drugs, are related to the pathogenesis of dental erosion. ${ }^{13,14,18}$

Some bleaching agents have a lower than ideal $\mathrm{pH}$, which can cause changes in the mineral content of the enamel, contributing to the formation of shallow depressions, increasing enamel porosity and promoting slight erosion. ${ }^{20}$ These changes can be higher when the contact time between bleaching agent and tooth surface is increased. ${ }^{21,22}$ However, studies have shown that the addition of calcium or fluoride to the composition of a bleaching agent can minimize mineral loss in the enamel..$^{23,24}$

Brushing is a hygiene procedure for maintaining oral health, usually done with abrasive dentifrices, and plays an important role in prevention of formation or removal of extrinsic stains. ${ }^{25,26}$ Nevertheless, the use of more abrasive toothpastes can increase wear on the tooth surface. ${ }^{27-29}$ Few in vitro studies have evaluated changes in the bleached enamel and dentin after methods of acid exposure or toothbrushing. ${ }^{30-33}$ The majority of studies have reported that the abrasive or erosive actions of combinations containing $10 \%$ carbamide peroxide ${ }^{30,32}$ or $35 \%$ hydrogen peroxide ${ }^{33}$ have no deleterious effects on enamel or dentin.

One study has evaluated the effect on enamel and dentin of the interaction between $10 \%$ carbamide peroxide bleaching, erosion with 1\% citric acid, and abrasion using low and high abrasive dentifrices. The authors concluded that bleaching did not increase the susceptibility of enamel to erosive and abrasive wear, but that dentin wear was affected by the interaction of bleaching, erosion, and dentifrices. ${ }^{30}$ Another study that evaluated the roughness of human enamel exposed to $10 \%$ carbamide peroxide showed that use of this concentration of bleaching agent alone did not alter enamel surface roughness, but when the bleaching treatment was associated with brushing using fluoridated or nonfluoridated abrasive dentifrices, there was a significant impact on enamel surface roughness. ${ }^{31}$

\section{Can bleaching alter properties of tooth structure?}

A number of studies have evaluated the influence of athome bleaching agents on the properties of enamel and dentin. . $^{24,30-32,34-51}$ Most of them have used the 10\% carbamide peroxide and different methodologies to investigate the softening effect produced by bleaching agents on mineralized dental tissues, including surface microhardness, surface morphology, surface roughness, and calcium loss.

While some studies have found no significant alteration in enamel surface caused by $7.5 \%-22 \%$ carbamide peroxide or $6 \%$ hydrogen peroxide, ${ }^{21,31,32,34-39}$ others showed that $10 \%-22 \%$ carbamide peroxide solutions can cause morphological changes and erosive lesions, decreasing microhardness and increasing enamel surface roughness. ${ }^{24,40-49}$ Therefore, the question arises as to whether these morphological changes in the enamel surface are transient, permanent, and/or clinically significant? 
In general, findings of damage to the enamel surface after bleaching treatment come from studies carried out in vitro, with the methodological limitations inherent in this type of study. Such findings may not be representative of the in vivo condition, in which the oral cavity is continually bathed with saliva containing various minerals, including fluoride, calcium, and phosphate, lipids, carbohydrates, proteins, and other substances ${ }^{44}$ Evaluation of specimens was usually performed soon after the bleaching protocols, without any period of storage in artificial saliva and consequently with no remineralizing effect. ${ }^{44,46-48}$ Storage in artificial saliva was performed only between clinical sessions or from the first to the last session..$^{24,40-49}$ The relevant studies identified in the MedLine database are summarized in Table 1, with information regarding the type of study, measurement used, tissue evaluated, product concentration, $\mathrm{pH}$ values, changes observed, and possible reversibility after remineralization.

Surface evaluations were performed by scanning electron microscopy ${ }^{24,42,43}$ or enamel microhardness ${ }^{41}$ after exposure to $10 \%-22 \%$ carbamide peroxide for $14,{ }^{24,41} 84,{ }^{42}$ and $90^{43}$ days. Erosive lesions were observed for periods up to 84 days after conclusion of bleaching ${ }^{42}$ and decreased microhardness even after 14 days. ${ }^{41}$ Basting et $\mathrm{al}^{41}$ showed that an increase in enamel microhardness occurred after the end of bleaching treatment, but without reaching baseline microhardness values. This can be explained by the absence in artificial saliva of proteins present in human saliva, which prevents the formation of the acquired pellicle, a protective barrier of dental tissue formed in vivo. Even though 10\% carbamide peroxide caused alterations in the surface morphology of enamel in one study, these alterations were reversed within 3 months following treatment. ${ }^{43}$ Additionally, it was observed that enamel microhardness decreased after bleaching treatments containing $10 \%$ carbamide peroxide with or without fluoride, but hardness values gradually recovered after cessation of bleaching. ${ }^{24}$ These discrepant results may be attributed to wide variation in methodology, which may limit any comparisons between studies.

Using scanning electron microscopy to compare in vitro and in situ methodologies to detect effects of $10 \%$ carbamide peroxide on enamel topography, calcium loss, and microhardness, Justino et a ${ }^{52}$ observed that test conditions played an important role in deleterious effects. While rougher surface, higher mineral loss, and lower microhardness were observed for bleaching treatment performed in vitro, such alterations were not detected in situ, which is very similar to the in vivo condition. In Figure 1 the effects of $10 \%$ carbamide peroxide treatment on the enamel surface can be seen, and the different patterns of erosion caused by $10 \%$ carbamide peroxide using in vitro and in situ methodologies are compared with unbleached enamel.

Some authors have reported that the erosive effect associated with bleaching treatment may be related to the low $\mathrm{pH}$ of the whitening solutions. ${ }^{24,43,45}$ However, when enamel erosion was detected after bleaching with 10\%-22\% carbamide peroxide, the products used generally had $\mathrm{pH}$ values ranging from 6 to 7.8 , ie, neutral or very close to neutral. ${ }^{24,40,41,43,47,48}$ One study used an agent with an acidic $\mathrm{pH}(4.7),{ }^{44}$ but the others did not evaluate the $\mathrm{pH}$ of the solutions tested. ${ }^{42,46}$ Such findings demonstrate that morphological changes induced by bleaching procedures could not be exclusively related to $\mathrm{pH} .{ }^{40}$

An investigation was conducted to evaluate the time period required to re-establish enamel surface microhardness after bleaching with fluoridated or nonfluoridated $10 \%$ carbamide peroxide gels with neutral or acidic $\mathrm{pH}$ that used a daily demineralization and remineralization protocol. After seven days of whitening treatment, a statistically significant loss of hardness ranging from $7 \%-15 \%$ was observed in all groups. Nevertheless, fluoridated gels provided some protective effect, with less loss of hardness than with the nonfluoridated gels. The $\mathrm{pH}$ of acidic gels does not seem to contribute significantly to demineralization of enamel. ${ }^{49}$

No significant changes in surface roughness of the enamel have been observed after bleaching with $10 \%{ }^{31}$ or $16 \%^{21}$ carbamide peroxide, but susceptibility to abrasion was increased when brushing was performed with abrasive toothpaste..$^{21,31}$ However, these studies were carried out in vitro, so would have had more pronounced effects than in conditions in vivo. Another study ${ }^{39}$ evaluated enamel microhardness after bleaching with $10 \%$ carbamide peroxide, and the authors were unable to find a significant difference before and after bleaching, but their study did show decreased resistance to abrasion. Additionally, the authors observed that bleached enamel showed a greater loss of tooth structure when abraded against both a harshly and mildly abrasive substrate than the unbleached enamel did. ${ }^{39}$

The potentially higher susceptibility of bleached enamel to erosion and demineralization was also evaluated in a study of human incisors. The study was designed to determine if enamel bleached using different carbamide peroxide gel concentrations of $10 \%, 16 \%, 22 \%$, or $10 \%$ and containing xylitol, fluoride, and potassium, had an increased risk of either acid erosion or demineralization as compared with unbleached enamel. The authors observed that erosion was detected in all samples, and that there was no statistically significant 


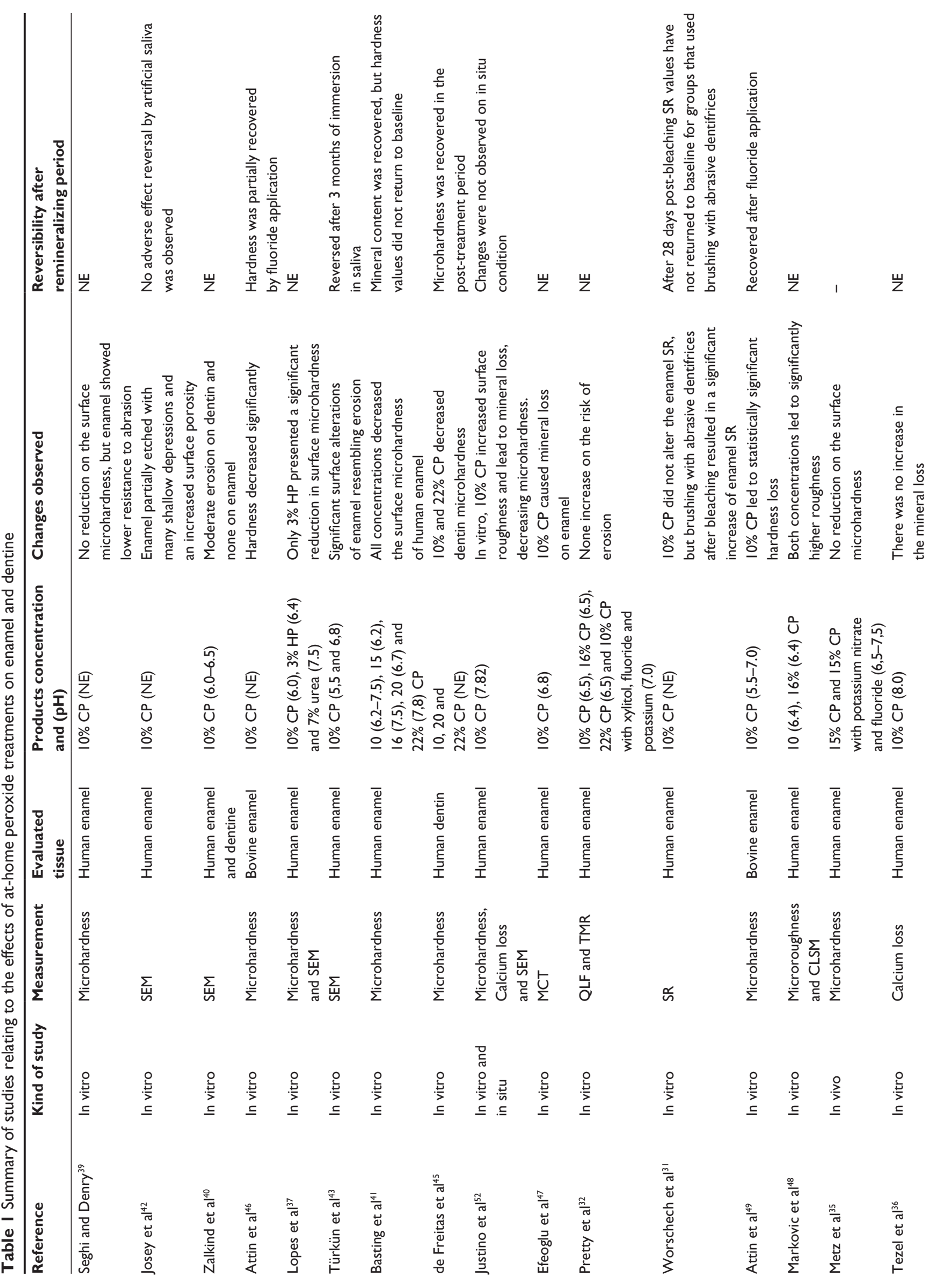



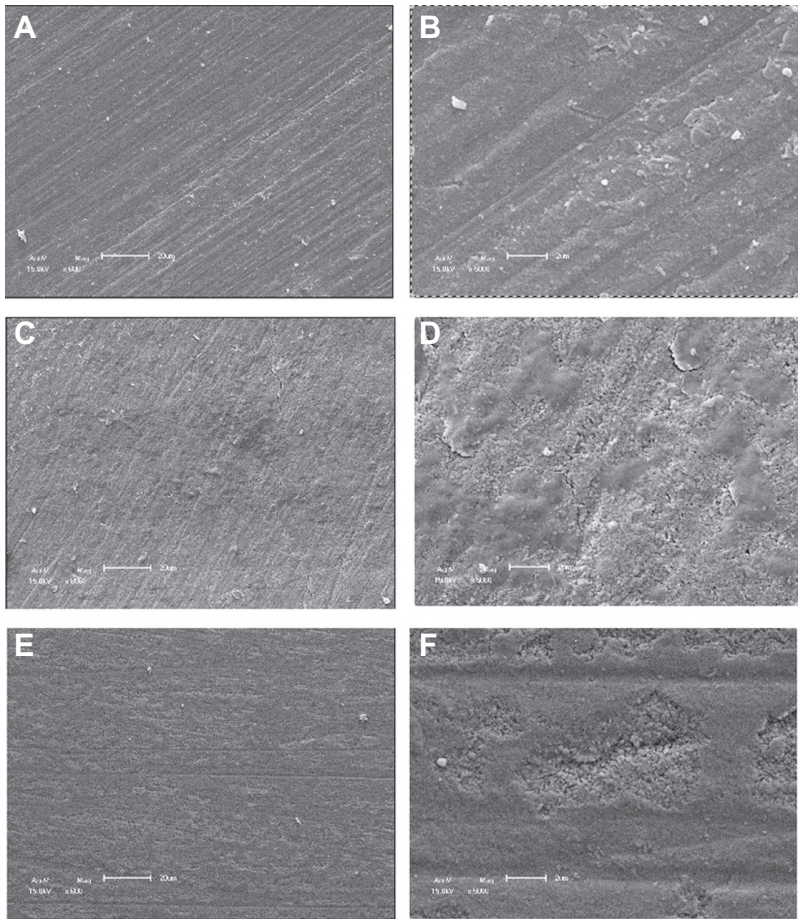

Figure I Scanning electron microscopic analysis of unbleached human enamel and bleached enamel under in vitro or in situ conditions. ( $\mathbf{A}$ and $\mathbf{B}$ ) lower and higher magnification of unbleached enamel, with no signs of eroded structure. (C and D) lower and higher magnification of $10 \%$ carbamide peroxide-treated enamel, using in vitro methodology. The enamel has altered surface topography, showing loss of mineral structure and an eroded surface. ( $\mathbf{E}$ and $\mathbf{F}$ ) lower and higher magnification of $10 \% \mathrm{CP}$ treated enamel under in situ condition. The enamel has some altered surface, with localized mineral loss, which is lower than the mineral loss observed for bleached enamel in vitro.

Pictures courtesy of Dr Lidia M Justino, Univali, Brazil.

difference between the bleached and nonbleached areas, regardless of the bleaching agent used. When submitted to cariogenic challenges, all samples showed caries-like lesions, in bleached and unbleached specimens. They concluded that tooth bleaching with carbamide peroxide does not increase the susceptibility of enamel to acid erosion or demineralization as occurs during caries formation. ${ }^{32}$

Only one in vivo study evaluated the influence of at-home bleaching agents on enamel microhardness. This clinical trial compared the effects of a neutral fluoridated and a nonfluoridated whitening product, both containing $15 \%$ carbamide peroxide, on enamel microhardness after tooth extraction. ${ }^{35}$ The authors concluded that $15 \%$ carbamide peroxide with or without fluoride in the composition does not seem to alter enamel microhardness. This is in accordance with other in vitro studies using artificial saliva as the storage solution, in which investigators reported that $7.5 \%$ or $10 \%$ carbamide peroxide did not cause any significant alteration in enamel surface topography ${ }^{37}$ or microhardness. ${ }^{37,38}$ Additionally, another in vitro study that assessed the amount of calcium loss in enamel previously 
bleached using 10\% carbamide peroxide, did not detect an increase in enamel solubility. ${ }^{36}$ Furthermore, a study comparing the erosive effect of $6 \%$ hydrogen peroxide indicated for at-home tooth bleaching and that of orange juice concluded that the erosive effects of $6 \%$ hydrogen peroxide on enamel surface were not statistically significant compared with orange juice. ${ }^{34}$ The authors also reported that daily intake of acidic soft drinks was potentially more harmful to hard dental tissues than periodic application of hydrogen peroxide-based tooth bleaching products. ${ }^{34}$

\section{Different responses of dentin and enamel to bleaching agents}

Due to the highest organic content of dentin when compared with enamel, it has been suggested that dentin is more prone to mineral loss resulting from tooth bleaching. Some studies have evaluated the effect of carbamide peroxide on the dentin surface..$^{30,45,50,51}$ We found two studies, one in situ ${ }^{50}$ and the other in vitro ${ }^{30}$, that evaluated enamel and dentin resistance to abrasion after bleaching with $10 \%$ carbamide peroxide. Neither study found a significant effect of bleaching on enamel surface wear, but a higher wear depth was detected for bleached dentin, regardless of the abrasiveness of the dentifrice used. Moreover, even with the formation of an acquired pellicle being shown by the in situ study, there was still abrasion on the dentin surface. However, the analysis was done immediately after the bleaching protocol, without any period of recovery for the dental surface.

In summary, most of the studies have shown that athome tooth bleaching with low concentrations of hydrogen or carbamide peroxide have no significant harmful effects on enamel and dentin surface morphology, microhardness, roughness, or calcium loss. The few studies that showed alterations in enamel or dentin surfaces all had limitations in their in vitro methodology or used highly acidic bleaching agents. In addition, these harmful effects on tooth substrates were generally transitory, and were not significant when remineralization periods were allowed.

\section{Safety and tolerability}

At-home tooth bleaching with 10\% carbamide peroxide placed in a custom-tray is considered the safest and efficacious method of bleaching, having the additional benefits of a lower incidence of tooth sensitivity and gingival irritation. ${ }^{5,11,53,54}$ Although these side effects may occur, ${ }^{55,56}$ they usually disappear at the end of treatment. ${ }^{57,58}$ Gingival irritation could be attributed either to the design of the tray or to the concentration of the bleaching agent.
Interruption of treatment for 1-2 days or adjustment of the tray generally resolves this side effect. ${ }^{59}$

Tooth sensitivity may cause discomfort to the patient, but is a reversible effect that does not last more than 24 hours and rarely leads to cessation of treatment. ${ }^{60,61}$ Most sensitivity occurs within the first two weeks of treatment ${ }^{54}$ and it may be the result of the glycerine or other vehicle used to carry the active ingredient, which cause tooth dehydration, enabling easier penetration into dental tissues and leading to reversible pulpitis. ${ }^{62}$

The risk of tooth sensitivity increases if there is gingival recession with exposure of cementum and/or dentin. ${ }^{63}$ Combination of the bleaching agent with potassium nitrate and fluoride can reduce this undesirable effect. ${ }^{58}$ Another method that has been shown to be effective in reducing the intensity of tooth sensitivity is application of fluoride before the bleaching treatment. ${ }^{64}$ Additionally, manufacturers have introduced at-home bleaching gels with fluoride in their composition in order to decrease any post-treatment tooth sensitivity. ${ }^{8,23}$

Studies have reported that the histological modifications to the pulp after vital tooth bleaching with $10 \%$ carbamide peroxide might cause initial mild, localized pulp reactions. However, the minor histological changes observed did not affect the overall health of the pulp tissue and were reversible within two weeks post-treatment. ${ }^{65-67}$

Thus, at-home bleaching has shown to be a safe and well tolerated method for whitening teeth. The side effects, mainly tooth sensitivity and gingival irritation, are easily controlled when the correct technique is employed, with the use of a well adapted tray, an adequate amount of bleaching gel, and application of fluoride or desensitizing agents before and after treatment.

\section{Conclusion}

Based on the present literature review, the following conclusions could be drawn:

- The majority of the studies have shown that at-home tooth bleaching agents based on hydrogen or carbamide peroxide have no harmful effects on enamel and dentin properties.

- In vitro studies have shown that at-home tooth bleaching agents based on hydrogen or carbamide peroxide has no clinically relevant effect on enamel mineral loss caused by erosion or abrasion; additionally, artificial saliva is an efficient media for reversing possible mineral loss associated with bleaching treatment in vitro.

- The bleaching agents used in at-home tooth bleaching have shown satisfactory safety and tolerability, and any 
adverse effects can be easily controlled by application of fluoride or desensitizing agents between sessions, using well adapted trays or lower concentrations of bleaching agents.

- More randomized clinical trials are needed to have a better understanding of the effects of bleaching products on the predisposition to erosion and abrasion.

\section{Disclosure}

The authors report no conflicts of interest in this work.

\section{References}

1. Kihn PW. Vital tooth whitening. Dent Clin North Am. 2007;51(2): 319-331.

2. Matis BA, Cochran MA, Eckert G. Review of the effectiveness of various tooth whitening systems. Oper Dent. 2009;34(2):230-235.

3. Hasson H, Ismail AI, Neiva G. Home-based chemically-induced whitening of teeth in adults. Cochrane Database Syst Rev. 2006; 4:CD006202.

4. European Commission on Consumer Products. Scientific committee on consumer products opinion on hydrogen peroxide in tooth whitening products. 4:1-48; SCCP 0844, 2005. Available at: http://ec.europa. eu/health/ph_risk/committees/04_sccp/docs/sccp_cons_01_en.pdf. Accessed on July 12, 2011.

5. Meireles SS, Heckmann SS, Santos IS, Della Bona A, Demarco FF. A double blind randomized clinical trial of at-home tooth bleaching using two carbamide peroxide concentrations: 6-month follow-up. J Dent. 2008;36(11):878-884.

6. Matis BA, Cochran MA, Eckert GJ, Matis JI. In vivo study of two carbamide peroxide gels with different desensitizing agents. Oper Dent. 2007;32(6):549-555.

7. Browning WD, Blalock JS, Frazier KB, Downey MC, Myers ML. Duration and timing of sensitivity related to bleaching. J Esthet Restor Dent. 2007;19(5):256-264.

8. Armênio RV, Fitarelli F, Armênio MF, Demarco FF, Reis A, Loguercio AD. The effect of fluoride gel use on bleaching sensitivity: a double-blind randomized controlled clinical trial. J Am Dent Assoc. 2008;139(5):592-597.

9. Li Y, Lee SS, Cartwright SL, Wilson AC. Comparison of clinical efficacy and safety of three professional at-home tooth whitening systems. Compend Contin Educ Dent. 2003;24(5):357-360.

10. Demarco FF, Meireles SS, Masotti AS. Over-the-counter whitening agents: a concise review. Braz Oral Res. 2009;23(Suppl 1): 64-70.

11. American Dental Association. Consumer products with the ADA seal of acceptance. Available from: http:/www.ada.org/sections/ scienceAndResearch/pdfs/adaseal_consumer_shopping.pdf. Accessed 2011 Apr 1.

12. Litonjua LA, Andreana S, Bush PJ, Cohen RE. Tooth wear: attrition, erosion, and abrasion. Quintessence Int. 2003;34(6):435-446.

13. O’Sullivan E, Milosevic A; British Society of Paediatric Dentistry. UK National Clinical Guidelines in Paediatric Dentistry: diagnosis, prevention and management of dental erosion. Int J Paediatr Dent. 2008;18(Suppl 1):29-38.

14. Magalhães AC, Wiegand A, Rios D, Honório HM, Buzalaf MA. Insights into preventive measures for dental erosion. J Appl Oral Sci. 2009;17(2):75-86.

15. Addy M, Shellis RP. Interaction between attrition, abrasion and erosion in tooth wear. Monogr Oral Sci. 2006;20:17-31.

16. Hooper S, West NX, Pickles MJ, Joiner A, Newcombe RG, Addy M. Investigation of erosion and abrasion on enamel and dentine: a model in situ using toothpastes of different abrasivity. J Clin Periodontol. 2003;30(9):802-808.
17. Fujii M, Kitasako Y, Sadr A, Tagami J. Roughness and $\mathrm{pH}$ changes of enamel surface induced by soft drinks in vitro-applications of stylus profilometry, focus variation 3D scanning microscopy and micro $\mathrm{pH}$ sensor. Dent Mater J. 2011;30(3):404-410.

18. Lussi A, Hellwig E, Ganss C, Jaeggi T. Buonocore Memorial Lecture. Dental erosion. Oper Dent. 2009;34(3):251-262.

19. Mangueira DF, Sampaio FC, Oliveira AF. Association between socioeconomic factors and dental erosion in Brazilian schoolchildren. J Public Health Dent. 2009;69(4):254-259.

20. Bistey T, Nagy IP, Simó A, Hegedus C. In vitro FT-IR study of the effects of hydrogen peroxide on superficial tooth enamel. J Dent. 2007;35(4):325-330.

21. Mondelli RF, Azevedo JF, Francisconi PA, Ishikiriama SK, Mondelli J. Wear and surface roughness of bovine enamel submitted to bleaching. Eur J Esthet Dent. 2009;4(4):396-403.

22. Grobler SR, Majeed A, Moola MH. Effect of various tooth-whitening products on enamel microhardness. SADJ. 2009;64(10):474-479.

23. Cavalli V, Rodrigues LK, Paes-Leme AF, et al. Effects of bleaching agents containing fluoride and calcium on human enamel. Quintessence Int. 2010;41(8):e157-e165.

24. Chen HP, Chang CH, Liu JK, Chuang SF, Yang JY. Effect of fluoride containing bleaching agents on enamel surface properties. J Dent. 2008;36(9):718-725.

25. Joiner A. Whitening toothpastes: a review of the literature. J Dent. 2010;38(Suppl 2):e17-e24.

26. Gerlach RW, Barker ML, Hyde JD, Jones MB, Cordero RE. Effects of a tartar control whitening dentifrice on tooth shade in a population with long-standing natural stain. J Clin Dent. 2001;12(2):47-50.

27. Schemehorn BR, Moore MH, Putt MS. Abrasion, polishing, and stain removal characteristics of various commercial dentifrices in vitro. J Clin Dent. 2011;22(1):11-18.

28. Macdonald E, North A, Maggio B, et al. Clinical study investigating abrasive effects of three toothpastes and water in an in situ model. J Dent. 2010;38(6):509-516.

29. Vicentini BC, Braga SR, Sobral MA. The measurement in vitro of dentine abrasion by toothpastes. Int Dent J. 2007;57(5):314-318.

30. Engle K, Hara AT, Matis B, Eckert GJ, Zero DT. Erosion and abrasion of enamel and dentin associated with at-home bleaching: an in vitro study. J Am Dent Assoc. 2010;141(5):546-551.

31. Worschech CC, Rodrigues JA, Martins LR, Ambrosano GM. Brushing effect of abrasive dentifrices during at-home bleaching with $10 \%$ carbamide peroxide on enamel surface roughness. J Contemp Dent Pract. 2006;7(1):25-34.

32. Pretty IA, Edgar WM, Higham SM. The effect of bleaching on enamel susceptibility to acid erosion and demineralisation. Br Dent J. 2005;198(5):285-290.

33. Sulieman M. An overview of bleaching techniques: history, chemistry, safety and legal aspects (part 1). SADJ. 2006;61(7):304-310.

34. Ren YF, Amin A, Malmstrom $H$. Effects of tooth whitening and orange juice on surface properties of dental enamel. J Dent. 2009;37(6):424-431.

35. Metz MJ, Cochran MA, Matis BA, Gonzalez C, Platt JA, Pund MR. Clinical evaluation of $15 \%$ carbamide peroxide on the surface microhardness and shear bond strength of human enamel. Oper Dent. 2007;32(5):427-436.

36. Tezel H, Ertas OS, Ozata F, Dalgar H, Korkut ZO. Effect of bleaching agents on calcium loss from the enamel surface. Quintessence Int. 2007;38(4):339-347.

37. Lopes GC, Bonissoni L, Baratieri LN, Vieira LC, Monteiro S. Effect of bleaching agents on the hardness and morphology of enamel. J Esthet Restor Dent. 2002;14(1):24-30.

38. Sasaki RT, Arcanjo AJ, Flório FM, Basting RT. Micromorphology and microhardness of enamel after treatment with home-use bleaching agents containing 10\% carbamide peroxide and 7.5\% hydrogen peroxide. J Appl Oral Sci. 2009;17(6):611-616.

39. Seghi RR, Denry I. Effects of external bleaching on indentation and abrasion characteristics of human enamel in vitro. $J$ Dent Res. 1992;71(6):1340-1344. 
40. Zalkind M, Arwaz JR, Goldman A, Rotstein I. Surface morphology changes in human enamel, dentin and cementum following bleaching: a scanning electron microscopy study. Endod Dent Traumatol. 1996;12(2):82-88.

41. Basting RT, Rodrigues AL, Serra MC. The effects of seven carbamide peroxide bleaching agents on enamel microhardness over time. J Am Dent Assoc. 2003;134(10):1335-1342.

42. Josey AL, Meyers IA, Romaniuk K, Symons AL. The effect of a vital bleaching technique on enamel surface morphology and the bonding of composite resin to enamel. J Oral Rehabil. 1996;23(4):244-250.

43. Türkun M, Sevgican F, Pehlivan Y, Aktener BO. Effects of $10 \%$ carbamide peroxide on the enamel surface morphology: a scanning electron microscopy study. J Esthet Restor Dent. 2002;14(4):238-244.

44. Ushigome T, Takemoto S, Hattori M, Yoshinari M, Kawada E, Oda Y. Influence of peroxide treatment on bovine enamel surface - crosssectional analysis. Dent Mater J. 2009;28(3):315-323.

45. de Freitas PM, Turssi CP, Hara AT, Serra MC. Dentin microhardness during and after whitening treatments. Quintessence Int. 2004; 35(5):411-417.

46. Attin T, Kielbassa AM, Schwanenberg M, Hellwig E. Effect of fluoride treatment on remineralization of bleached enamel. J Oral Rehabil. 1997;24(4):282-286.

47. Efeoglu N, Wood D, Efeoglu C. Microcomputerised tomography evaluation of $10 \%$ carbamide peroxide applied to enamel. J Dent. 2005;33(7): 561-567.

48. Markovic L, Jordan RA, Lakota N, Gaengler P. Micromorphology of enamel surface after vital tooth bleaching. J Endod. 2007;33(5): 607-610.

49. Attin T, Betke H, Schippan F, Wiegand A. Potential of fluoridated carbamide peroxide gels to support post-bleaching enamel re-hardening. J Dent. 2007;35(9):755-759.

50. Faraoni-Romano JJ, Turssi CP, Serra MC. Effect of a 10\% carbamide peroxide on wear resistance of enamel and dentine: in situ study. $J$ Dent. 2009;37(4):273-278.

51. de Freitas PM, Turssi CP, Hara AT, Serra MC. Monitoring of demineralized dentin microhardness throughout and after bleaching. Am J Dent. 2004;17(5):342-346.

52. Justino LM, Tames DR, Demarco FF. In situ and in vitro effects of bleaching with carbamide peroxide on human enamel. Oper Dent. 2004;29(2):219-225.
53. Haywood VB. History, safety, and effectiveness of current bleaching techniques and applications of the nightguard vital bleaching technique. Quintessence Int. 1992;23(7):471-478.

54. Haywood VB. Treating sensitivity during tooth whitening. Compend Contin Educ Dent. 2005;26(9 Suppl 3):11-20.

55. Cibirka RM, Myers M, Downey MC, et al. Clinical study of tooth shade lightening from dentist-supervised, patient-applied treatment with two 10\% carbamide peroxide gels. J Esthet Dent. 1999;11(6):325-331.

56. Barnes DM, Kihn PW, Romberg E, George D, DePaola L, Medina E. Clinical evaluation of a new $10 \%$ carbamide peroxide tooth-whitening agent. Compend Contin Educ Dent. 1998;19(10):968-972.

57. Haywood VB. Current status of nightguard vital bleaching. Compend Contin Educ Dent Suppl. 2000;28:S10-S17.

58. dos Santos Medeiros MC, de Lima KC. Effectiveness of nightguard vital bleaching with $10 \%$ carbamide peroxide - a clinical study. J Can Dent Assoc. 2008;74(2):163.

59. Haywood VB, Heymann HO. Nightguard vital bleaching: how safe is it? Quintessence Int. 1991;22(7):515-523.

60. Heymann HO, Swift EJ, Bayne SC, et al. Clinical evaluation of two carbamide peroxide tooth-whitening agents. Compend Contin Educ Dent. 1998;19(4):359-362.

61. Buchalla W, Attin T. External bleaching therapy with activation by heat, light or laser - a systematic review. Dent Mater. 2007;23(5): 586-596.

62. Pohjola RM, Browning WD, Hackman ST, Myers ML, Downey MC. Sensitivity and tooth whitening agents. J Esthet Restor Dent. 2002; 14(2):85-91.

63. Sulieman MA. An overview of tooth-bleaching techniques: chemistry, safety and efficacy. Periodontol 2000. 2008;48:148-169.

64. Tay LY, Kose C, Loguercio AD, Reis A. Assessing the effect of a desensitizing agent used before in-office tooth bleaching. J Am Dent Assoc. 2009;140(10):1245-1251.

65. Fugaro JO, Nordahl I, Fugaro OJ, Matis BA, Mjör IA. Pulp reaction to vital bleaching. Oper Dent. 2004;29(4):363-368.

66. Fugaro OJ, Fugaro JO, Matis B, Gregory RL, Cochran MA, Mjör I. The dental pulp: inflammatory markers and vital bleaching. Am J Dent. 2005;18(4):229-232.

67. Pugh G, Zaidel L, Lin N, Stranick M, Bagley D. High levels of hydrogen peroxide in overnight tooth-whitening formulas: effects on enamel and pulp. J Esthet Restor Dent. 2005;17(1):40-45.
Clinical, Cosmetic and Investigational Dentistry

\section{Publish your work in this journal}

Clinical, Cosmetic and Investigational Dentistry is an international, peer-reviewed, open access, online journal focusing on the latest clinical and experimental research in dentistry with specific emphasis on cosmetic interventions. Innovative developments in dental materials, techniques and devices that improve outcomes and patient satisfac-

\section{Dovepress}

tion and preference will be highlighted. The manuscript management system is completely online and includes a very quick and fair peerreview system, which is all easy to use. Visit http://www.dovepress. com/testimonials.php to read real quotes from published authors. 